\title{
PENGENALAN PENCATATAN DAN PENGGUNAAN PROGRAM KEUANGAN PADA UMKM KULINER DI ULUJAMI
}

\author{
Dwiyasko Wicaksono $^{1}$, Bambang Eko Samiono ${ }^{1}$ \\ ${ }^{1}$ Universitas Al-Azhar Indonesia \\ yascod@gmail.com, be.samyono@uai.ac.id
}

\begin{abstract}
Abstrak
UMKM Kuliner yang berada pada sepanjang jalan Ulujami Raya merupakan sekelompok pedagang yang menjual berbagai produk kuliner baik makanan maupun minuman di tepi jalan dengan menggunakan tenda ataupun kios kecil. Mereka menempati bahu jalan atau menyewa di mini market setempat. Selama pandemi covid ini mereka cukup terimbas utamanya terjadinya penurunan omset harian. Dari temuan di lapangan diperoleh adanya permasalahan yang mereka hadapi diantaranya 1) ketidakcakapan UMKM kuliner dalam mengelola keuangan usaha hingga sering tercampur dengan keuangan keluarga dan 2) tidak adanya pencatatan keuangan dalam usaha mereka yang mengakibatkan pengelolaan usaha menjadi tidak jelas. Melalui kegiatan KKN pengabdian kepada masyarakat, Tim mahasiswa pengabdian masyarakat mengupayakan solusi berupa 1) kegiatan pengenalan pencatatan keuangan usaha dan 2) kegiatan pengenalan pencatatan keuangan usaha dengan menggunakan aplikasi keuangan secara sederhana. Kegiatan ini dilakukan secara daring mengingat pelaksanaannya dilakukan disaat PPKM. Hasil yang diperoleh setelah dilakukan evaluasi terhadap program dilaksanakan adalah terdapat tingkat kepuasan mitra $83.6 \%$ dengan metode CSI dan adanya peningkatan pengetahuan UMKM kuliner dalam pengelolaan keuangan dan penggunaan aplikasi keuangan.
\end{abstract}

Kata Kunci : umkm, aplikasi keuangan, pencatatan keuangan, kkndaring

\section{PENDAHULUAN}

Ulujami adalah kelurahan di kecamatan Pesanggrahan yang merupakan wilayah padat penduduk dengan mayoritas warganya berasal dari luar kota Jakarta. Kelurahan ini memiliki Luas Wilayah $1.71 \mathrm{Km}^{2}$, terdiri dari 5,480 Keluarga, 88 RT, 8 RW [1][2] . Kehidupan masyarakat di wilayah Ulujami sangat kental dengan agama Islam, hal tersebut tercermin dari adanya kegiatan pengajian rutin di hampir semua masjid yang ada, dan juga adanya pondok pesantren Darul Najjah. Selain itu dari segi budaya di wilayah tersebut terdapat pengurus pusat Rang Chaniago yang merupakan salah satu suku dari Padang, dan juga pos Forum Betawi Rempug yang rutin menggelar acara kumpul-kumpul setiap bulannya.

Penghasilan mayoritas masyarakat yang melakukan usaha berasal dari usaha konveksi dan bekerja sebagai penjahit konveksi, hal tersebut didukung dengan akses menuju ITC Cipulir yang merupakan salah satu pusat perbelanjaan yang cukup besar untuk konveksi atau pakaian. Selain itu juga membuka warung atau berjualan di sepanjang jalan Ulujami Raya yang merupakan akses utama yang cukup ramai.

Berfokus pada para pelaku UMKM kuliner yang berjualan berjajar di hampir sepanjang jalan 
Ulujami dengan usaha dibidang makanan dan minuman. Terlihat bahwa selain terdapat pedagang yang bertahun-tahun membuka usaha disana ada juga beberapa di antaranya sudah ada yang memiliki nama yang cukup dikenal masyarakat berbentuk franchise atau usaha busines opportunity. Di sisi lain, ada juga beberapa pelaku UMKM yang juga baru memulai usaha akibat adanya pandemi COVID-19, baik karena menurunnya perekonomian ataupun kehilangan pekerjaan.

Dari pemantauan tim pengabdian masyarakat terhadap beberapa UMKM yang baru memulai ataupun UMKM lama yang belum berkembang terlihat adanya beberapa kondisi seperti: 1) Dalam pengelolaan pemasaran terpantau 50-60\% dari UMKM ada yang sudah menerapkan digital marketing secara pasif utamanya penggunaan channel distribusi produk mereka, seperti terdaftar sebagai merchant Go-Food, Grab Food, ataupun Shopee Food. Namun teknologi tersebut belum membantu secara maksimal karena masih hanya menunggu pelanggan datang. Untuk pengemasan produk, $30-40 \%$ di antara mereka ada yang sudah memperhatikan packaging produk secara tepat. Baik untuk tujuan pemasaran ataupun kesehatan. Sementara selebihnya masih mengandalkan pengemasan standart dengan Styrofoam, plastic kiloan ataupun kertas koran. 2) Untuk pengelolaan operasional mengingat skala usaha mereka masih kecil dan sederhana serta ada beberapa yang merupakan usaha business opportunity terlihat tidak ada kesulitan berarti yang mereka temui. Sedangkan 3) Dalam pengelolaan keuangan terpantau bahwa mereka melakukan pencatatan transaksi, pencatatan modal, dan cashflow secara manual dengan menulis pada buku atau bahkan $80 \%$ lainnya tidak melakukan pencatatan transaksi baik untuk keluar atau masuknya uang. Bukan itu saja dari pendalaman wawancara yang dilakukan mereka tidak mengerti dasar-dasar pengelolaan keuangan usaha. Bahkan mereka terbiasa untuk mencampurkan keuangan pribadi dengan keuangan usaha. Dan beberapa hal yang mempengaruhi hal ini adalah perbedaan pendidikan [3]. Terlebih lagi untuk penggunaan aplikasi POS atau Point of Sale terlihat belum bayak di antara mereka yang mengenalnya. Padahal saat ini POS merupakan aplikasi yang umum dipakai oleh para pelaku usaha pada masa sekarang bahkan banyak versi gratisnya.

Kondisi pengelolaan keuangan pada UMKM yang baru memulai ataupun UMKM lama yang belum berkembang ini menarik perhatian Tim Pengabdian Masyarakat. Utamanya kondisi para UKM tersebut yang belum mengenal pengelolaan keuangan usaha menggunakan aplikasi POS. Mengingat banyak fitur yang dapat dimanfaatkan oleh UMKM terhadap usahanya, seperti memonitor penjualan, memonitor bahan baku, pengelolaan harga dan produk, hingga fitur kasir sekalipun [4] [5], namun penggunaan teknologi tersebut pada UMKM masih sangat kecil dengan data dari Kominfo menyebutkan hanya sebanyak 3,79 juta atau $8 \%$ dari total 58,97 juta UMKM yang ada di Indonesia [6]. Dan dari pengamatan di lapangan, penggunaan teknologi POS pada UMKM paling banyak digunakan oleh UMKM yang sudah skala pasar dan modalnya sudah cukup besar.

\section{Permasalahan}
Dari pemaparan kondisi tersebut tim pengabdian masyarakat memfokuskan permasalahan mitra UMKM kuliner pada beberapa hal diantaranya yaitu:

1) Ketidakcakapan mitra UMKM kuliner dalam mengelola keuangan usaha hingga sering tercampur dengan keuangan keluarga.

2) Tidak adanya pencatatan keuangan dalam usaha mereka yang mengakibatkan pengelolaan usaha menjadi tidak jelas

\section{Solusi Permasalahan}

Dalam program pengabdian masyarakat yang merupakaan perpanjangan dari program KKN mahasiswa Universitas Al-Azhar Indonesia dengan tema "Pengembangan masyarakat digital agar mampu bertahan dan bersaing di masa pandemi covid-19 di beberapa daerah di Jakarta Selatan" ini., ini beberapa solusi di upayakan. Diantaranya adalah: 
1) Kegiatan pengenalan pencatatan keuangan usaha: Program ini diberikan sebagai solusi agar mitra UKM memperoleh dasar pengetahuan mengenai pengelolaan keuangan usaha. Dimana dalam prakteknya harus dipisahkan dengan pengelolaan keuangan keluarga.

2) Kegiatan pengenalan pencatatan keuangan usaha dengan menggunakan aplikasi keuangan secara sederhana: program ini diberikan sebagai pengenalan literasi digital kepada mitra UMKM. Dimana dengan menggunakan aplikasi tidak berbayar mitra UMKM bisa mendapatkan kemudahan dalam mengelola keuangan usahanya meski dalam skala sederhana.

\section{METODE}

\section{Waktu Pelaksanaan}

Program pengabdian masyarakat ini dilaksanakan setiap hari Minggu selama 4 minggu berturut-turut, dengan durasi pelaksanaan 90 hingga 120 menit. Pelaksanaan pertama dilakukan pada tanggal 27 Juni 2021.

\section{Pelaksanaan}

Seluruh kegiatan pengabdian masyarakat ini dilaksanakan secara daring menyesuaikan dengan kebijakan pemerintah mengenai pembatasan kegiatan masyarakat dan menghindari kerumunan dengan memanfaatkan aplikasi Zoom Meeting. Pelaksanaan program kegiatan ini diberikan kepada lima UMKM Kuliner yang memiliki usaha di sekitar jalan Ulujami.
Tabel 1. Rencana Kegiatan Pengabdian Masyarakat

\begin{tabular}{|c|c|c|c|}
\hline Program & Metode & Luaran & $\begin{array}{c}\text { Alokasi } \\
\text { Waktu }\end{array}$ \\
\hline $\begin{array}{l}\text { Sosialisasi } \\
\text { pengenalan } \\
\text { program kerja } \\
\text { dan penentuan } \\
\text { peserta. }\end{array}$ & $\begin{array}{l}\text { Luring- } \\
\text { Daring }\end{array}$ & $\begin{array}{l}\sim \text { Daftar peserta } \\
\text { yang akan } \\
\text { mengikuti } \\
\text { program ini. } \\
\sim \text { Calon peserta } \\
\text { paham mengenai } \\
\text { program yang } \\
\text { akan dilaksanakan } \\
\text { serta manfaatnya }\end{array}$ & 9 jam \\
\hline $\begin{array}{l}\text { Pengenalan } \\
\text { pengelolaan } \\
\text { keuangan usaha } \\
\text { secara umum }\end{array}$ & Daring & $\begin{array}{l}\text { Peserta mengerti } \\
\text { manfaat } \\
\text { melakukan } \\
\text { pencatatan } \\
\text { terhadap usahanya }\end{array}$ & 2 jam \\
\hline $\begin{array}{l}\text { Pengenalan } \\
\text { pencatatan } \\
\text { keuangan usaha } \\
\text { yang baik dan } \\
\text { benar }\end{array}$ & Daring & $\begin{array}{l}\text { Peserta mengerti } \\
\text { bagaimana } \\
\text { melakukan } \\
\text { pencatatan yang } \\
\text { baik sesuai } \\
\text { dengan usaha } \\
\text { mereka. }\end{array}$ & 2 jam \\
\hline $\begin{array}{l}\text { Pemanfaatan } \\
\text { aplikasi } \\
\text { keuangan untuk } \\
\text { melakukan } \\
\text { pencatatan } \\
\text { keuangan usaha }\end{array}$ & Daring & $\begin{array}{l}\text { Peserta mengenal } \\
\text { dan mengerti } \\
\text { penggunaan } \\
\text { aplikasi POS } \\
\text { (Point of Sale) } \\
\text { untuk usaha } \\
\text { mereka. }\end{array}$ & 2 jam \\
\hline $\begin{array}{l}\text { Monitoring dan } \\
\text { Evaluasi }\end{array}$ & $\begin{array}{l}\text { Daring } \\
\text { Group } \\
\text { WA }\end{array}$ & $\begin{array}{l}\text { Hasil evaluasi } \\
\text { mengenai } \\
\text { implementasi } \\
\text { yang dilakukan } \\
\text { mitra atas } \\
\text { kegiatan yang } \\
\text { telah dilaksanakan }\end{array}$ & 1 bulan \\
\hline
\end{tabular}

\section{HASIL DAN PEMBAHASAN}

Pelaksanaan pengabdian masyarakat ini karena merupakan rangkaian program KKN online yang diadakan universitas serta terbentur adanya pelaksanaan PPKM, maka beberapa kegiatan dan waktu harus beberapa kali dilakukan penyesuaian. Berikut disampaikan hasil kegiatan tersebut: 


\section{Sosialisasi pengenalan program kerja dan penentuan peserta:}

Dalam kegiatan penentuan peserta tim pengabdian masyarakat cukup kerepotan mengingat adanya beberapa kali perpanjangan PPKM di Jakarta membuat beberapa peserta yang sudah ditetapkan terpaksa tidak beroperasi hingga mengurungkan niatnya untuk menjadi mitra kegiatan sehingga menyebabkan berkurangnya peserta dalam program kegiatan ini. Namun Tim pengabdian tetap berupaya memenuhi 5 kuota yang telah ditetapkan sebelumnya.

Sosialisasi pengenalan program kerja dan penentuan peserta pada pelaksanaannya sesuai dengan jadwal dan rancangan kegiatan, dilakukan secara luring dengan cara turun langsung ke lapangan untuk berkomunikasi dengan tetap menerapkan protokal Kesehatan yang ketat. Pada kegiatan ini yang dilakukan adalah mengunjungi 5 UMKM kuliner yang ada di sepanjang jalan Ulujami Raya untuk meminta izin agar dapat menjadi peserta kegiatan pengabdian masyarakat dan mendengarkan permasalahan yang mereka hadapi dengan mengenalkan program kerja yang akan dilaksanakan untuk membantu menyelesaikan permasalahan yang mereka hadapi.

Yang dihasilkan dari kegiatan ini adalah ditentukannya UMKM tersebut sebagai mitra kegiatan KKN yang terdiri dari 1) Penjual Hotang Jalan Perdatam Terusan 2) Penjual Bebek Goreng Jalan Ulujami Raya 3) Penjual Sosis \& Bakso Bakar di Jalan Ulujami Raya 4) Warung Kopi di Jalan H. Dilun, dan 5) Penjual Ayam Geprek di Jalan Ulujami Raya.

\section{Pengenalan Pengelolaan Keuangan Usaha:}

Program inti pengenalan pengelolaan usaha yang baik dan benar terdiri dari 3 materi yaitu Pengelolaan Keuangan Usaha, Pencatatan Keuangan Usaha dan Penggunaan Aplikasi Pencatatan Keuangan Usaha. Dalam pelaksanaannya ketiga kegiatan tersebut berjalan dengan baik meski beberapa kendala muncul karena penggunaan metode daring yang harus diterapkan selama PPKM. Seperti kesiapan penggunaan zoom oleh peserta yang tidak terbiasa, kesiapan peserta dalam menerima materi karena pengaruh lingkungan sekitarnya saat itu sehingga peserta tidak mampu untuk focus dan juga masalah sinyal. Tim pun kesulitan untuk bisa secara langsung mendapatkan timbal balik ataupun peserta bisa mempraktekkan saat itu juga materi yang diberikan.

Materi mengenai pengeloalan dan pencatatan keuangan usaha cukup mudah diterima karena secara praktek masih terkait dengan pengelolaan usaha mereka. Sementara untuk materi pengguanaan aplikasi keuangan (POS) untuk pengelolaan keuangan usaha dipilihlah aplikasi POS dari Odoo [7], pemilihan aplikasi POS tersebut dilakukan dengan pertimbangan ada fitur trial yang memudahkan peserta juga bisa mencoba selain beberapa fitur pokoknya yang telah standart lengkap. Kepada para peserta juga diinformasikan bahwa peserta bebas memilih produk POS apapun dalam penerapannya, hal terpenting adalah merepa paham penggunaan aplikasi ini untuk diimplementasikan dalam usaha mereka. Pada kegiatan kali ini peserta terlihat sangat antusias dan tertarik dengan pemaparan pelaksana. 


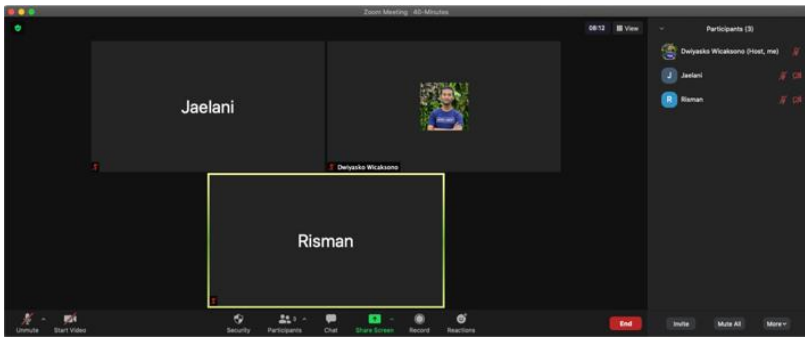

Gambar 1. (Zoom Meeting Pengenalan Aplikasi POS Odoo)

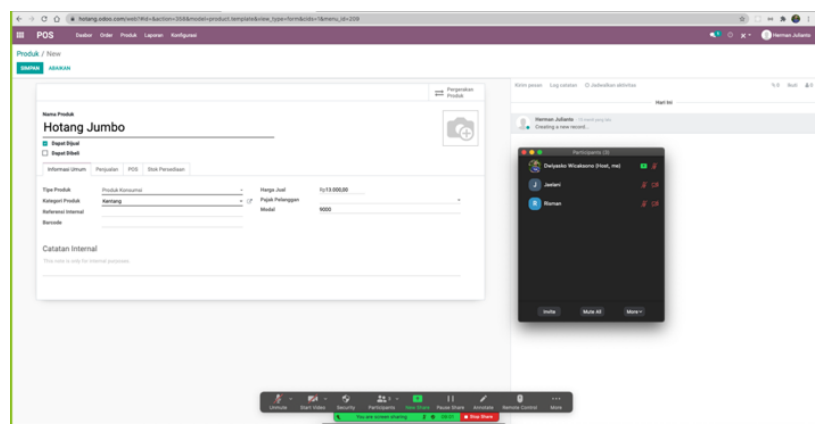

Gambar 2. (Demo Penggunaan Aplikasi POS Odoo)

\section{Monitoring dan Evaluasi:}

Kegiatan ini dilakukan selama 1 bulan untuk memantau upaya implementasi program yang telah dilakukan oleh mitra UKM. Kegiatan ini dilakukan untuk mengantisipasi ketidak maksimalan pemahaman saat materi pengenalan dipaparkan secara daring. Monitoring dilakukan baik daring maupun luring dengan menemui mereka secara langsung untuk memantau, berdiskusi dan menjawab pertanyaan-pertanyaan mereka. Secara daring monitoring ini dilakukan selalui WA dan dilakukan berkala.

Diakhir masa mentoring tahap evaluasi dilakukan dengan metode survey untuk mengetahui beberapa indikator keberhasilan yang di tetapkan. Dan beberapa hasil evaluasi yang tim pengabdian masyarakat dapatkan adalah:
Tabel 2. Tabel Hasil Evaluasi

\begin{tabular}{lll}
\hline \multicolumn{1}{c}{ Indikator } & \multicolumn{3}{c}{ Hasil } \\
\hline $\begin{array}{l}\text { Pengetahuan } \\
\text { Pengelolaan Keuangan }\end{array}$ & $\begin{array}{l}\text { Seluruh mitra UMKM } \\
\text { mengetahui dan paham akan manfaat } \\
\text { dan prinsip pengelolaan laporan } \\
\text { keuangan usaha }\end{array}$ & $\begin{array}{c}\text { Kuliner } \\
\text { man }\end{array}$ \\
\hline $\begin{array}{l}\text { Penerapan Pengelolaan } \\
\text { Keuangan }\end{array}$ & $\begin{array}{l}\text { Sebagian mitra UMKM kuliner mulai } \\
\text { menerapkan pencatatan keuangan }\end{array}$ \\
\hline $\begin{array}{l}\text { Penerapan aplikasi } \\
\text { pengelolaan keuangan }\end{array}$ & $\begin{array}{l}\text { Sebagian mitra UMKM kuliner mencoba } \\
\text { beberapa aplikasi keuangan dan } \\
\text { menyatakan adanya manfaat yang }\end{array}$ \\
Kepuasan Mitra UKM & Angka kepuasan 83,6\% & \\
$\begin{array}{l}\text { Terhadap Program } \\
\text { (metode CSI) }\end{array}$ & & \\
\hline
\end{tabular}

\section{KESIMPULAN}

Pandemi Covid-19 cukup memberi dampak bagi para UMKM, utamanya masalah ekonomi. Pandemi ini juga membuat UMKM-UMKM kuliner baru khususnya mulai bermunculan. Upaya untuk memberi pondasi pengetahuan mengenai pengetahuan akan pengelolaan keuangan usaha menjadi hal yang penting agar dimasa sulit ini mereka bisa lebih cakap dalam mengatur keuangan mereka dalam bisnis.

Program pengabdian masyarakat yang merupakaan perpanjangan dari program KKN mahasiswa Universitas Al-Azhar Indonesia dengan tema "Pengembangan masyarakat digital agar mampu bertahan dan bersaing di masa pandemi covid-19 di beberapa daerah di Jakarta Selatan" cukup responsive untuk dilaksanakan di waktu yang tepat. Beberapa kendala yang dihadapi terkait adanya PPKM yang menjadikan sebagian besar kegiatan ini harus dilakukan secara daring menjadi catatan sendiri untuk bisa di optimalkan pada pelaksanaan pengabdian masyarakat selanjutnya.

Program kegiatan pengenalan pencatatan keuangan usaha dan Kegiatan pengenalan pencatatan keuangan usaha dengan menggunakan aplikasi keuangan secara sederhana yang telah dilaksanakan terlihat berhasil memberikan mitra UMKM kuliner pemahaman dasar dalam berwirausaha hal ini sesuai dengan hasil evaluasi yang diperoleh. Tidak saya adanya peningkatan pengetahuan peserta namun juga sebagian mitra 
UMKM telah mengaplikasikannya dan mulai mencopa penggunaan aplikasi tersebut. Tingkat kepuasan peserta terhadap pelaksanaan program inipun cukup baik diangka $83.6 \%$.

\section{REFERENSI}

[1] Badan Pusat Statistik. Data Statistik Kependudukan wilayah Indonesia. https://jakselkota.bps.go.id/

[2] Data Wilayah Jakarta Selatan. Data kependudukan wilayah tegal parang, Mampang Prapatan. https://selatan.jakarta.go.id/tegal parang/

[3] Suryani, S \& Ramadhan, S (2017). Analisis literasi keuangan pada pelaku usaha mikro di Kota pekanbaru. Journal of Economic, Business and Accounting (COSTING) Volume 1 No 1, Desember 2017
[4] Mangmang, G. (2018). Development and Implementation of Point of Sale System (POS): Profitability Measurement for Retail Business. JOURNAL OF EDUCATIONAL AND HUMAN RESOURCE DEVELOPMENT, 6, 220226.

[5] Sipayung, E., Fiarni Cut., \& Wawan. (2020). Evaluasi Penggunaan Aplikasi Point of Sale Menggunakan Technology Acceptance Model pada UMKM. Jurnal Nasional Teknik Elektro dan Teknologi Informasi Vol. 9, No. 1, Februari 2020

[6] "Kemenkop UKM: 3,79 Juta UMKM Sudah Go Online,"[Online], https:// www.kominfo.go.id/ content/ detail/ 11526/ kemenkopukm - 379 - juta umkm-sudah-go-online/0/sorotan_media, tanggal akses: 3-Sept-2021.

[7] "Aplikasi Kasir (Point of Sale)," [Online], https://www.odoo.com/app/point-of-saleshop, tanggal akses: 3-Sept-2021. 